\title{
Analisis Akuntabilitas Penyelenggaraan Kewenangan Dekonsentrasi Pada Kantor Badan Lingkungan Hidup Provinsi Sulawesi Utara
}

\section{CHINTIA S. ALENG ${ }^{1}$, GRACE B. NANGOI ${ }^{2}$, WINSTON PONTOH ${ }^{3}$}

\author{
${ }^{1,2,3}$ Program Magister Akuntansi, Fakultas Ekonomi dan Bisnis Universitas Sam Ratulangi \\ email: cintania_3006@yahoo.com ${ }^{1}$,gracebn@yahoo.com²,winston_pontoh@yahoo.com ${ }^{3}$
}

\begin{abstract}
The purpose of this research is to analyze the accountability of the implementation of deconcentration authority in Badan Lingkungan Hidup Provinsi Sulawesi Utara. This is a qualitative research with case study approach. Data were obtained by in-depth interviews, observation and documentation study. Key informants were determined by purposive sampling based on the criterias in order to get the exact and accurate information. Interviews were then transcribed into data transcription. They were analyzed, given code, and categorized into themes. Data were analysed by content analysis. The result of research show that the implementation of deconcentration authority in Badan Lingkungan Hidup Sulawesi Utara is conducted based on technical guidance for the implementation of environmental deconcentration authority that involve direction policy, planning, budgeting, implementation, reporting, monitoring and evaluation, performance assesment, guidance and supervision. However, the implementation of deconcentration is not yet accountable. It is because of the inefficient planning, ineffective maximization of the fundings source in prioritising regional needs optimally. The obstacles in implementing the programs successfully are: (1) rationalization of budget from central government to local government; (2) delay in deconcentration reporting to KPPN Manado; (3) inadequate availability of supporting facilities of deconcentration program implementation; (4) ineffective guidance and supervision. These obstacles have caused the determined target can not be accomplished in accordance to the achievement of realization.
\end{abstract}

Keywords : Accountability, Authority Delegation, deconcentrated fund, Work Program.

\begin{abstract}
Abstrak. Penelitian ini bertujuan untuk menganalisis akuntabilitas penyelenggaraan kewenangan dekonsentrasi pada Kantor Badan Lingkungan Hidup Provinsi Sulawesi Utara. Penelitian ini menggunakan metode kualitatif dengan pendekatan studi kasus. Data diperoleh dengan teknik wawancara mendalam, observasi dan studi dokumentasi. Informan kunci ditetapkan secara purposive sampling dengan syarat memenuhi kriteria yang ditetapkan untuk mendapatkan informasi yang tepat dan akurat. Hasil wawancara di-transcribe menjadi transkrip data, kemudian dianalisis, diberi kode, dan dikategorikan ke dalam tema. Analisis data menggunakan analisis isi. Hasil penelitian menunjukan bahwa Penyelenggaraan Kewenangan Dekonsentrasi pada Kantor Badan Lingkungan Hidup Provinsi Sulawesi Utara dilaksanakan berdasarkan petunjuk teknis penyelenggaraan dekonsentrasi bidang lingkungan hidup meliputi arah kebijakan, perencanaan, penganggaran, pelaksanaan, pelaporan, pemantauan dan evaluasi, penilaian kinerja, serta pembinaan dan pengawasan. Namun penyelenggaraan dana dekonsentrasi belum akuntabel, hal ini dikarenakan perencanaan yang belum efektif dan efisien dalam memaksimalkan sumber dana secara optimal untuk memprioritaskan kebutuhan daerah. Hambatan keberhasilan program disebabkan : (1) proses rasionalisasi anggaran dari pemerintah pusat kepada pemerintah daerah; (2) masih adanya keterlambatan pelaporan dekonsentrasi ke KPPN Manado; (3) belum memadainya ketersediaan sarana dan prasarana penunjang pelaksanaan program dekonsentrasi; (4) pembinaan dan pengawasan dekonsentrasi yang belum efektif dalam pelaksanaannya. Hal tersebut menyebabkan target yang telah ditetapkan belum sesuai dengan pencapaian realisasi.
\end{abstract}

Kata Kunci : Akuntabilitas, Pelimpahan Kewenangan, Dana Dekonsentrasi, Program Kerja.

\section{Pendahuluan}

Penyelenggaraan pemerintahan daerah merupakan salah satu amanat Undang-Undang Dasar Negara Kesatuan Republik Indonesia (UUD NKRI) Tahun 1945. Pasal 18, Pasal 18A, dan Pasal 18B UUD 1945 menyebutkan bahwa pemerintahan daerah mengatur dan mengurus sendiri urusan pemerintahan menurut asas otonomi dan tugas pembantuan. Pelaksanaan otonomi ini diarahkan untuk mempercepat terwujudnya kesejahteraan masyarakat melalui peningkatan pelayanan, pemberdayaan, dan peran serta masyarakat, serta peningkatan daya saing daerah dengan memperhatikan prinsip demokrasi, pemerataan, keadilan, keistimewaan dan kekhususan suatu daerah dalam sistem Negara Kesatuan Republik Indonesia (NKRI).

Terselenggaranya good governance merupakan prasyarat utama mewujudkan aspirasi masyarakat mencapai tujuan dan cita-cita bangsa dan negara. Dalam rangka hal tersebut, diperlukan pengembangan dan penerapan sistem pertanggungjawaban pemerintah yang tepat, jelas dan nyata sehingga penyelenggaraan pemerintahan dan pembangunan dapat berdaya guna, berhasil guna dan 
bertanggungjawab serta bebas KKN. Amanat UUD 1945 dimaksud, secara eksplisit menegaskan tiga (3) hal penting, yaitu: pertama, terkait dengan hubungan kewenangan; kedua, hubungan keuangan; dan ketiga, menyangkut penyelenggaraan pemerintahan daerah, yang pelaksanaannya diatur lebih lanjut dengan undang-undang tersendiri. Landasan hukum penyelenggaraan pemerintahan daerah saat ini adalah UU No.32 Tahun 2004 tentang Pemerintahan Daerah dan Undang-Undang Nomor 33 tahun 2004 Tentang Perimbangan Keuangan antara Pemerintah Pusat dan Pemerintahan Daerah, beserta peraturan pelaksanaan lainnya.

Pada dasarnya pemerintah mulai level pusat sampai daerah sebagai agen pelaksanaan penyelenggaraan pemerintah diserahi "kekuasaan" oleh rakyat untuk melaksanakan pemerintahan demi mewujudkan peranya sebagai pelaksana pembangunan, pembuat regulasi, pemberi layanan kepada masyarakat dan pemberdaya masyarakat. Oleh karena itu pemerintah sebagai pihak yang diberi kekuasaan hendaknya memiliki kewajiban untuk mempertanggungjawabkan kekuasaan yang diberikan rakyat kepada mereka. Untuk mewujudkan pertanggungjawaban pemerintah terhadap warganya salah satu cara dilakukan dengan menggunakan prinsip transparansi (keterbukaan). Melalui transparansi penyelenggaraan pemerintahan, masyarakat diberikan kesempatan untuk mengetahui kebijakan yang akan dan telah diambil oleh pemerintah. Juga melalui transparansi penyelenggaraan pemerintahan tersebut, masyarakat dapat memberikan feedback atau outcomes terhadap kebijakan yang telah diambil oleh pemerintah.

Undang-Undang Nomor 32 Tahun 2004 khususnya Pasal 10 ayat (4) menyebutkan "Dalam menyelenggarakan urusan pemerintahan sebagaimana dimaksud pada ayat (3) pemerintah menyelenggarakan sendiri atau dapat melimpahkan sebagian urusan pemerintahan kepada perangkat pemerintah atau wakil pemerintah di daerah atau dapat menugaskan kepada pemerintahan daerah dan/atau pemerintahan desa". Selanjutnya ayat 5 menyebutkan "Dalam urusan pemerintahan yang menjadi kewenangan Pemerintah di luar urusan pemerintahan sebagaimana dimaksud pada ayat (3), Pemerintah dapat: a) menyelenggarakan sendiri sebagian urusan pemerintahan, b) Melimpahkan sebagian urusan pemerintahan kepada Gubernur selaku wakil pemerintah, atau c) Menugaskan sebagian urusan kepada pemerintahan daerah dan/atau pemerintahan desa berdasarkan asas tugas pembantuan". Pasal 12 ayat (2) UU No. 32 Tahun 2004 juga menyebutkan "Urusan pemerintahan yang dilimpahkan kepada Gubernur disertai dengan pendanaan sesuai dengan urusan yang didekonsentrasikan."

Dalam Undang-undang Nomor 32 Tahun 2004 disebutkan bahwa Dekonsentrasi adalah pelimpahan wewenang pemerintahan oleh Pemerintah pada Gubernur sebagai wakil pemerintah dan/atau kepada instansi vertikal diwilayah tertentu. Dalam pelaksanaan dekonsentrasi tentunya disertai dengan proses pendanaan yang menyangkut urusan tersebut, yang disebut dana dekonsentrasi, dimana Dana Dekonsentrasi adalah dana yang berasal dari Anggaran Pendapatan dan Belanja Negara yang dilaksanakan oleh Gubernur sebagai wakil pemerintah yang mencakup semua penerimaan dan pengeluaran dalam rangka pelaksanaan dekonsentrasi tidak termasuk dana yang dialokasikan untuk instansi vertikal pusat di daerah. Dalam rangka memberikan pedoman dalam pelaksanaan dekonsentrasi dan tugas pembantuan, pemerintah telah menetapkan Peraturan Pemerintah (PP) Nomor 7 Tahun 2008 tentang Dekonsentrasi dan Tugas Pembantuan yang secara normatif mengatur antara lain:

1) Dana dekonsentrasi dan tugas pembantuan hanya digunakan untuk mendanai program/kegiatan yang menjadi urusan pemerintah pusat. Oleh karena itu, kementerian/lembaga wajib memprakarsai penyusunan program/kegiatan dekonsentrasi dan tugas pembantuan sesuai dengan Renstra KL, Rencana Kerja KL dan ketentuan pembagian urusan,

2) Rencana lokasi dan anggaran untuk program dan kegiatan yang akan didekonsentrasikan/ditugas bantuankan disusun dengan memperhatikan kemampuan keuangan negara, keseimbangan pendanaan di daerah dan kebutuhan pembangunan daerah,

3) Pendanaan tugas pembantuan ditujukan untuk kegiatan yang bersifat fisik yaitu kegiatan yang output-nya berimplikasi terhadap penambahan nilai aset pemerintah, sementara output belanja bantuan sosial atau belanja barang tidak berimplikasi terhadap penambahan nilai aset pemerintah tersebut,

4) Semua barang yang dibeli atau diperoleh dari pelaksanaan dana dekonsentrasi dan tugas pembantuan merupakan barang milik negara $(\mathrm{BMN})$. Barang tersebut dapat dihibahkan kepada daerah dan apabila sudah dihibahkan, maka daerah wajib mengelola dan menatausahakannya sebagai barang milik daerah. 
PP No. 7 Tahun 2008 tentang Dekonsentrasi dan Tugas Pembantuan ditindaklanjuti dengan Peraturan Menteri Keuangan (PMK) Nomor 156 Tahun 2008 yang disempurnakan dengan PMK No. 248 Tahun 2010 tentang Pedoman Pengelolaan Dana Dekonsentrasi dan Dana Tugas Pembantuan yang mengatur tentang hal-hal terkait dengan pola dan mekanisme pendanaan dekonsentrasi dan tugas pembantuan yang wajib diikuti oleh seluruh penyelenggaraan kegiatan dekonsentrasi dan tugas pembantuan. Pengaturan pendanaan tersebut bertujuan agar pengelolaan dana dekonsentrasi dan dana tugas pembantuan dilakukan sesuai dengan prinsip-prinsip pengelolaan keuangan negara, sebagaimana diamanatkan dalam Pasal 3 ayat (1) UU Nomor 17 Tahun 2003 tentang Keuangan Negara yaitu, "Keuangan Negara wajib dikelola secara tertib, taat pada peraturan perundang-undangan, efisien, ekonomis, efektif, transparan dan bertanggungjawab dengan memperhatikan rasa keadilan dan kepatutan".

Kementerian Lingkungan Hidup Republik Indonesia menetapkan Permen LH No 10 Tahun 2013 tentang Petunjuk Teknis Penyelenggaraan Dekonsentrasi Bidang Lingkungan Hidup Tahun 2014 dan Permen LH No 9 Tahun 2014 tentang Petunjuk Teknis Penyelenggaraan Dekonsentrasi Bidang Lingkungan Hidup Tahun 2015 yang merupakan pedoman dan prosedur dan wajib digunakan sebagai acuan atas penyelenggaraan Dekonsentrasi untuk memastikan bahwa pelaksanaannya dilakukan sesuai juknis dan pelaksanaannya terus diupayakan agar selalu konsisten mengacu pada aturan yang telah ditentukan, baik aturan dalam Sistem Pelaksanaannya maupun pertanggungjawabannya. Permen LH No 10 Tahun 2013 dan Permen LH No 9 Tahun 2014 meliputi pengaturan mengenai: Arah kebijakan, Perencanaan, Penganggaran, Pelaksanaan, Pelaporan, Pemantauan dan evaluasi, Penilaian Kinerja, Pembinaan dan pengawasan. Badan Lingkungan Hidup Provinsi Sulawesi Utara merupakan salah satu Instansi Pemerintah yang melaksanakan Urusan Penyelenggaraan Dekonsentrasi Bidang Lingkungan Hidup. Walaupun dalam prakteknya, penyelenggaraan kewenangan Dekonsentrasi didaerah khususnya pada Kantor Badan Lingkungan Hidup Provinsi Sulawesi Utara telah berjalan sesuai Peraturan Pemerintah Nomor 7 Tahun 2008 serta Peraturan Menteri Keuangan No 156 Tahun 2008 tentang Pedoman Pengelolaan Dana Dekonsentrasi dan Tugas Pembantuan, namun sejauh ini masih ada ketidakkonsistenan dalam penerapan pelaksanaannya.

Berdasarkan Laporan Hasil Pemeriksaan (LHP) Dekonsentrasi tahun 2014 sampai dengan tahun 2015 terdapat beberapa kelemahan atas aspek kehematan, efisiensi, efektifitas dan ketaatan terhadap peraturan perundang-undangan yang perlu mendapat perhatian. Studi kasus dalam penelitian ini di batasi pada aspek kesesuaian berdasarkan Laporan Hasil Pemeriksaan program pelaksanaan kegiatan dana Dekonsentrasi pada BLH Provinsi Sulut Tahun 2014 dan Tahun 2015 tanpa mencantumkan nilai dalam rekomendasi sebagaimana kutipan berikut:

1. Pelaksanaan program pengembangan sumber daya alam dan lingkungan hidup di Provinsi

Sulawesi Utara tahun 2014 tidak optimal sehingga mengakibatkan pencapaian sasaran, kebijakan dan tujuan program pengelolaan sumber daya alam dan lingkungan hidup tidak terpenuhi.

2. Pertanggungjawaban keuangan Tahun 2014 tidak sesuai ketentuan sehingga mengakibatkan keterlanjuran pembayaran.

3. Belanja sewa tidak sesuai ketentuan sehingga mengakibatkan pemborosan keuangan negara.

4. Pertanggungjawaban keuangan Tahun 2015 tidak sesuai ketentuan sehingga mengakibatkan keterlanjuran pembayaran.

Adanya ketidaksesuaian antara perencanaan dan pelaksanaan program serta ketidakterpaduan pemahaman atas penyelenggaraan program dekonsentrasi menyebabkan pencapaian sasaran, kebijakan dan tujuan program belum dapat terpenuhi sehingga data realisasi pada akhir tahun belum memenuhi target pencapaian tujuan organisasi. Lemahnya peran atas fungsi pembinaan dan pengawasan terhadap tugas pokok dan fungsi pelaksana program, kegiatan dekonsentrasi mengakibatkan pelaksanaanya belum sesuai prosedur dan tupoksi masing-masing pelaksana serta mempengaruhi pencapaian pertanggungjawaban program dekonsentrasi.

Fungsi pengendalian internal terkait pembinaan dan pengawasan terhadap program dekonsentrasi yang semestinya dapat berperan mengefektifkan setiap tahapan pengelolaan keuangan negara belum dapat dimaksimalkan sehingga peneliti tertarik untuk melakukan penelitian ini dengan menganalisis akuntabilitas penyelenggaraan dekonsentrasi sesuai dengan juknis dekonsentrasi dan mendalami penyelenggaraan terkait arah kebijakan dekonsentrasi, perencanaan, penganggaran, pelaksanaan, pelaporan, pemantauan dan evaluasi, penilaian kinerja dan pembinaan pengawasan dekonsentrasi pada BLH Prov Sulut. 
Tujuan yang ingin dicapai dari penelitian ini adalah untuk menganalisis bagaimana akuntabilitas penyelenggaraan kewenangan dekonsentrasi pada kantor Badan Lingkungan Hidup Provinsi Sulawesi Utara berdasarkan Permen LH No 10 Tahun 2013 dan Permen LH No 9 Tahun 2014 tentang Petunjuk Teknis Penyelenggaraan Dekonsentrasi Bidang Lingkungan Hidup TA 2014 dan 2015.

\section{Metode Penelitian}

Penelitian ini merupakan penelitian kualitatif dengan jenis penelitian studi kasus (case study) pada Kantor Badan Lingkungan Hidup Provinsi Sulawesi utara. Creswell (2007: 39-40) menjelaskan bahwa Penelitian Kualitatif digunakan ketika ingin: (1) Menggali masalah yang ada dan mendapat jawaban yang lebih baik dibandingkan dengan hanya melihat informasi dari literature dan berdasarkan hasil riset yang lain, (2) Mengetahui secara detail dan lengkap tentang masalah yang diteliti, (3) Memberdayakan informan sehingga peneliti mendapat jawaban dari permasalahan mereka berawal dari analisa data sampai interpretasi, (4) Mengetahui dalam konteks apa informan memberikan informasinya, (5) Menindaklanjuti hasil penelitian kualitatif sehingga mendapatkan jawaban atas pertanyaan-pertanyaan pada rumusan masalah.

Creswell (2007) mengemukakan studi kasus merupakan strategi penelitian dimana di dalamnya peneliti menyelidiki secara cermat suatu program, peristiwa, aktivitas, proses, atau sekelompok individu. Kasus-kasus dibatasi oleh waktu dan aktivitas, dan peneliti mengumpulkan informasi secara lengkap dengan menggunakan berbagai prosedur pengumpulan data berdasarkan waktu yang telah ditentukan. Peneliti studi kasus berupaya menelaah sebanyak mungkin data mengenai subjek yang diteliti.

Teknik pengumpulan data yang dilakukan dalam penelitian ini adalah wawancara, Observasi, dan studi dokumentasi atau gabungan ketiganya yang disebut triangulasi. Analisis data dalam penelitian kualitatif dilakukan sebelum memasuki lapangan, selama dilapangan, dan setelah selesai dilapangan. Miles and Huberman dalam (Sugiyono, 2011) mengemukakan aktifitas dalam analisis data kualitatif dilakukan secara interaktif dan berlangsung secara terus menerus sampai tuntas, sehingga datanya sudah jenuh. Aktivitas dalam analisis data mencakup, data reduction, data display, dan data conclusion drawing/verification. Prosedur pengolahan data yang telah dikumpulkan adalah sebagai berikut: (1) Membuat transkrip wawancara (interviews transcriptions), (2) Melakukan analisis data. Analisis data yang digunakan dalam penelitian ini menggunakan analisis isi (content analysis). Analisis isi dimulai dengan melakukan coding terhadap istilah-istilah atau penggunaan kata dan kalimat yang relevan, yang paling banyak muncul dalam media komunikasi.. Setelah dikategorikan kemudian dimasukkan ke dalam tema, (3) Melakukan Validitas data. Pengujian keabsahan data dilakukan dengan menyandingkan antara sumber data dengan data lainnya, yaitu data yang diperoleh dari hasil wawancara, observasi dan studi dokumentasi, (4) Mengambil kesimpulan dari hasil penelitian. Pengambilan kesimpulan berdasarkan analisis data yang telah diuji keabsahannya.

\section{Analisis dan Pembahasan}

Penelitian dilakukan pada bulan Juni hingga September 2017 dengan melakukan wawancara secara mendalam (in-depth interview) kepada informan yang berwenang dan berkaitan langsung dengan subjek penelitian untuk memperoleh informasi terkait yang dilakukan selama 30 sampai 60 menit. Data kualitatif berupa data primer diperoleh dari sumber informan yaitu Inspektorat KLHK, dan pegawai pada BLH Prov Sulut yang berkaitan langsung dengan pengelolaan program dekonsentrasi. Kemudian data sekunder diperoleh melalui studi dokumen pelimpahan urusan pemerintahan dekonsentrasi LH, Permen LH, DIPA, Juknis Dekonsentrasi bidang LH.

Peraturan Menteri Lingkungan Hidup Republik Indonesia No. 10 Tahun 2013 tentang Petunjuk Teknis Penyelenggaraan Dekonsentrasi Bidang Lingkungan Hidup TA 2014 dan Peraturan Menteri Lingkungan Hidup dan Kehutanan Republik Indonesia Nomor 09 Tahun 2014 tentang Petunjuk Teknis Penyelenggaraan Dekonsentrasi Bidang Lingkungan Hidup Tahun Anggaran 2015. Petunjuk teknis dekonsentrasi bidang lingkungan hidup digunakan sebagai acuan bagi institusi pengelola lingkungan hidup tingkat Provinsi untuk melaksanakan tugas dekonsentrasi. Peraturan menteri ini bertujuan untuk memberikan pedoman bagi unit kerja dilingkungan Kementerian Lingkungan Hidup dan Pemerintah Provinsi dalam menyelenggarakan dekonsentrasi bidang LH. Peraturan Menteri ini meliputi pengaturan mengenai : (1) arah kebijakan; (2) perencanaan; (3) penganggaran; (4) pelaksanaan; (5) pelaporan; (6) pemantauan dan evaluasi; (7) penilaian kinerja; dan (8) pembinaan dan pengawasan. Tingkat akuntabilitas dalam penyelenggaraan kewenangan 
dekonsentrasi pada Badan Lingkungan Hidup Provinsi Sulawesi Utara mencakup 8 Aspek yang digambarkan secara jelas didalam juknis penyelenggaraan dekonsentrasi.

\section{Arah Kebijakan Dekonsentrasi Bidang Lingkungan Hidup}

Arah kebijakan pelaksanaan dekonsentrasi lingkungan hidup adalah untuk mendorong percepatan pencapaian sasaran prioritas nasional. Jika prioritas nasional telah tercapai sesuai dengan sasaran dan tujuannya, maka penyelenggaraan dekonsentrasi dapat dikatakan telah efektif dan akuntabel. Penjelasan Peraturan Pemerintah Nomor 7 Tahun 2008 tentang Dekonsentrasi dan Tugas Pembantuan, bahwa penyelenggaraan dekonsentrasi harus terus diupayakan pelaksanaannya agar selalu konsisten mengacu pada aturan yang telah ditentukan, baik aturan dalam Sistem Pemerintahan maupun aturan dalam Sistem Pengelolaan Keuangan Negara. Arah kebijakan pelaksanaan dekonsentrasi bidang LH sebagai percepatan pencapaian kesejahteraan masyarakat di daerah khususnya Pemprov Sulut disektor LH. Hal ini sesuai dengan pasal 258 ayat 3 UU No 23 tahun 2014 yang menjelaskan bahwa Kementerian atau lembaga pemerintah nonkementerian berdasarkan pemetaan urusan Pemerintahan wajib yang tidak berkaitan dengan Pelayanan Dasar dan urusan pemerintahan sebagaimana dimaksud dalam pasal 24 melakukan sinkronisasi dan harmonisasi dengan daerah untuk mencapai target pembangunan nasional.

Arah kebijakan penyelenggaraan dekonsentrasi pada BLH Prov Sulut secara mutlak menjadi hak daripada daerah dengan tujuan untuk mensejahterakan masyarakat di daerah sehingga bukan sekedar kepercayaan Pemerintah Pusat kepada Pemerintah Daerah dalam mendukung tercapainya pembangunan nasional namun diperlukan kesiapan perangkat daerah termasuk juga dalam segi ketertiban administrasi. Menurut Oosterveer dan Vliet (2010) keterlibatan daerah dalam pengelolaan lingkungan sangat penting karena mereka yang lebih memahami potensi sumber daya alam dan permasalahan lingkungan yang terjadi didaerahnya, sehingga diharapkan dengan pelibatan daerah akan lebih efektif daripada kebijakan terpusat.

Kebijakan dekonsentrasi dipandang dapat meningkatkan kinerja perlindungan dan pengelolaan LH didaerah secara berkelanjutan. Arah kebijakan dekonsentrasi yang dilaksanakan oleh BLH Prov Sulut bertujuan agar supaya SKPD atau satker dekonsentrasi selaku instansi teknis melalui program dekonsentrasi memiliki data series mengenai pengendalian pencemaran. Data series ini menjadi penting karena dapat menjadi landasan bagi daerah khususnya Sulawesi Utara untuk pengambilan atas arah kebijakan dekonsentrasi yang sifatnya antisipatif dalam memanfaatkan sumber daya alam secara berkelanjutan didaerah sesuai dengan aspek kesesuaian prioritas pembangunan nasional bidang lingkungan hidup dengan indikator kualitas daya dukung lingkungan sebagaimana tertuang dalam RKP dan RPJMN Kementerian/Lembaga tahun 2010-2014 yang menunjukan kondisi kualitas lingkungan hidup di Indonesia.

\section{Perencanaan}

Perencanaan program disusun dan pelaksanaannya disesuaikan oleh Sekretariat Jenderal cq. Biro Perencanaan Kementerian Lingkungan Hidup dan Kehutanan. Mekanisme tersebut menjadi pedoman sekaligus sebagai landasan dalam perencanaan dan menjadi prinsip dalam akuntabilitas penyelenggaraan kewenangan dekonsentrasi. Pasal 3 UU No. 17 Tahun 2003 tentang keuangan negara menyebutkan bahwa Keuangan negara wajib dikelola secara tertib, taat pada peraturan perundangundangan, efisien, ekonomis dan efektif, transparan, dan bertanggungjawab dengan memperhatikan rasa keadilan dan kepatutan.

Perencanaan dekonsentrasi secara jelas mengacu pada juknis dekonsentrasi yaitu Permen LH No 9 Tahun 2014 yang secara jelas mengatur bahwa penetapan target indikator kinerja dan penetapan alokasi anggaran dekonsentrasi bidang LH ditetapkan oleh Menteri, sehingga program dan kegiatan yang dianggarkan didalam APBN khususnya melalui dana dekonsentrasi disesuaikan dengan program yang dianggarkan oleh APBD sehingga penganggaran program dan kegiatannya mewakili satu mata penganggaran dan tidak tumpang tindih dalam penganggarannya. Sebagai penunjang program APBD, sudah seharusnya perencanaan dekonsentrasi benar-benar memperhatikan kebutuhan atau prioritas kebutuhan daerah melalui sektor lingkungan hidup.

Kepala Badan Lingkungan Hidup selaku Kuasa Pengguna Anggaran berkewajiban menyelenggarakan proses perencanaan administrasi keuangan dana dekonsentrasi sesuai dengan Peraturan Menteri Keuangan dan Petunjuk teknis dekonsentrasi yang berlaku. Berhasil tidaknya pelaksanaan anggaran tergantung kepada efektifitas pengendalian perencanaan kerja yang dilakukan oleh organisasi. Hal ini sesuai dengan pendapat Nafarin (2007:30) menjelaskan bahwa "pengendalian 
berarti mengevaluasi (menilai) terhadap pelaksanaan pekerjaan dengan cara: (1) Membandingkan realisasi dengan rencana (anggaran), (2) Melakukan tindakan perbaikan bila dipandang perlu atau bila terdapat penyimpangan merugikan.

\section{Penganggaran}

Penganggaran kegiatan dekonsentrasi pada BLH Prov Sulut dilakukan setelah ditetapkan dalam Rencana Kerja Pemerintah (RKP) sampai dengan Renja Kementerian/Lembaga dan telah mendapatkan kesepakatan dari daerah dalam hal ini Gubernur untuk bersedia melaksanakan kegiatan dekonsentrasi, maka selanjutnya ditindaklanjuti dengan penganggaran. Pengalokasian dana dalam RKA/KL pada BLH Prov Sulut dilakukan dengan memperhatikan program dan kegiatan yang telah ditetapkan. Atas dasar data dukung dan RKA/KL maka Kementerian/Lembaga mengajukan pembahasan RKA/KL Kepada Kementerian Keuangan untuk dilakukan penelaahan. Setelah RKA/KL disetujui sampai dengan terbitnya SAPSK maka dokumen tersebut disampaikan kepada SKPD atau BLH Provinsi Sulut sebagai bahan untuk menyusun konsep DIPA yang diajukan kepada Kanwil Ditjen Perbendaharaan setempat. Atas dasar usulan DIPA tersebut Kanwil Perbendaharaan meneliti kesesuaian dengan Perpres rincian APBN dan Satuan Anggaran per Satuan Kerja (SAPSK) untuk dasar pengesahan DIPA. Setelah DIPA ditetapkan maka SKPD dapat mulai menjalankan kegiatan dekonsentrasi terhitung mulai 1 Januari pada tahun berjalan. Rencana Kerja Anggaran (RKA) dekonsentrasi bidang LH merupakan bagian dari RKA-KLHK

Menurut R.A Supriyono yang dikutip oleh Tendi Haruman dan Sri Rahayu (2007:9) menyatakan bahwa prinsip-prinsip dasar yang harus dipenuhi dan ditaati agar suatu anggaran dapat disusun dan dilaksanakan sesuai dengan rencana adalah sebagai berikut : (a) Management Involvement; (b) Organizational Adaption; (c) Responsibility Accounting; (d) Full Communication; (e) Timeliness; (e) Reward and Punishment. Penganggaran dekonsentrasi pada prinsipnya disesuaikan dengan prioritas sesuai dengan juknis sehingga tidak keluar dari aturan yang telah ditetapkan oleh pemerintah pusat yaitu program Kementerian Lingkungan Hidup dan Kehutanan untuk menentukan kualitas lingkungan hidup yang lebih baik.

\section{Pelaksanaan Dekonsentrasi}

Pelaksanaan teknis setiap keluaran (output) kegiatan khususnya pengendalian pencemaran dana dekonsentrasi bidang LH berpedoman pada petunjuk teknis pelaksanaan yang ditetapkan oleh eselon I yang menjadi Pembina kegiatan terkait sesuai dengan tata laksana pengorganisasian pelaksanaan kegiatan dan dilaksanakan sesuai dengan ketentuan perundang-undangan APBN. Tolok ukur kinerja adalah ukuran keberhasilan yang dicapai pada setiap program atau kegiatan dalam satu tahun anggaran tertentu.

Menurut Rudianto (2013), kinerja merupakan gambaran pencapaian pelaksanaan suatu kegiatan atau program dalam mewujudkan visi, misi, tujuan dan sasaran organisasi. Tolok ukur kinerja digunakan sebagai dasar pengukuran kinerja keuangan dalam sistem anggaran kinerja, terutama untuk menilai kewajaran anggaran biaya suatu program atau kegiatan. Output daripada pelaksanaan program kegiatan pada BLH Prov Sulut tercermin dari dokumen-dokumen laporan hasil pelaksanaan teknis kegiatan. Dapat disimpulkan bahwa pelaksanaan dekonsentrasi pada BLH Prov Sulut merupakan kesatuan pekerjaan atau kegiatan yang dilaksanakan oleh para pegawai BLH Prov Sulut yang memiliki aspek teknis khusus serta saling berkaitan satu sama lain menurut sifat atau pelaksanaanya untuk mencapai tujuan dalam sebuah organisasi perangkat daerah.

Sistematis pelaksanaan dekonsentrasi pada BLH Prov Sulut tidak terlepas dari pada rasionalisasi anggaran. Meskipun hal tersebut merupakan kebijakan dan kewenangan pemerintah pusat namun sebagai pelaksana kegiatan dekonsentrasi didaerah tidak terlepas dari program kebijakan pemerintah pusat, sehingga mau ataupun tidak mau pemerintah daerah harus menerapkannya walaupun prosesnya dapat menghambat penyerapan realisasi anggaran penyelenggaraan dekonsentrasi didaerah khususnya pada BLH Prov Sulut.

\section{Pelaporan Dekonsentrasi}

Laporan akuntabilitas disusun sesuai dengan ketentuan peraturan perundang-undangan dan petunjuk teknis yang ditetapkan oleh Menteri Keuangan. Laporan manajerial dan laporan akuntabilitas disampaikan setiap 3 (tiga) bulan oleh Kepala SKPD Provinsi sebagai satuan kerja pelaksana dekonsentrasi bidang LH kepada Kepala Biro yang mempunyai tugas, pokok dan fungsi perencanaan, program dan anggaran Kementerian Lingkungan Hidup dan Kehutanan. 
Munawir (2010:31) berpandangan bahwa Laporan keuangan merupakan alat yang sangat penting untuk memperoleh informasi sehubungan dengan posisi keuangan dalam hasil-hasil yang telah dicapai. Hal ini sesuai dengan Permendagri No 101 Tahun 2016 Pasal 20 ayat 2 yang mengatur tanggungjawab pelaksanaan fisik dan kegiatan sesuai dengan yang telah ditetapkan dalam daftar isian pelaksanaan anggaran (DIPA) yang berfungsi sebagai dasar untuk melakukan tindakan yang mengakibatkan pengeluaran negara dan pencairan dana atas beban APBN serta dokumen pendukung kegiatan akuntansi pemerintah dan memuat informasi satuan-satuan terukur yang berfungsi sebagai dasar pelaksanaan kegiatan dan pengunaan anggaran, alat pengendali, pelaksanaan, pelaporan, pengawasan dan perangkat akuntansi pemerintah yang pelaksanaannya harus dapat dipertanggungjawabkan.

\section{Pemantauan dan Evaluasi}

Data realisasi pada tahun 2014 dan tahun 2015 pada Kantor BLH Prov Sulut menunjukan bahwa pemantauan dan evaluasi terhadap realisasi fisik dan keuangan pada BLH Prov Sulut adalah dalam rangka meningkatkan efisiensi dan efektifitas pemantauan dan evaluasi pelaksanaan dekonsentrasi secara berkala guna untuk mengetahui dengan pasti kemajuan dan kendala yang dijumpai dalam pelaksanaan kegiatan tersebut. Tahun 2014 menunjukan realisasi pelaksanaan dekonsentrasi sebesar $86,3 \%$, hal ini menggambarkan bahwa pelaksanaan dekonsentrasi pada dasarnya telah berjalan dengan baik. Namun pada tahun 2015, pagu dan realisasi hanya sebesar $77,7 \%$. Dapat dijelaskan bahwa pada tahun 2015 pelaksanaan dekonsentrasi mengalami penurunan pagu anggaran yang disebabkan atas kebijakan penggabungan dari Kementerian Lingkungan Hidup dan Kementerian Kehutanan. Hal ini menjadi penyebab capaian realisasi mengalami penurunan disebabkan adanya rasionalisasi anggaran atas kebijakan Pemerintah pusat yang juga berdampak pada pendanaan didaerah khususnya Sulawesi Utara.

Masih adanya keterlambatan penyampaian pelaporan dari BLH Prov Sulut kepada Kantor KPPN Manado. Pelaksanaan administrasi keuangan dalam hal pelaporan keuangan merupakan hal yang penting karena menyangkut kewajiban yang harus dipatuhi oleh Satker dana Dekonsentrasi dalam rangka kepatuhan terhadap penyampaian laporan sesuai dengan PMK No 156/PMK.07/2008 tentang Pedoman Pengelolaan Dana Dekonsentrasi dan Dana Tugas Pembantuan. Bentuk informasi yang disajikan oleh bagian akuntansi adalah laporan keuangan sebagai bentuk pertanggungjawaban manajemen terhadap pihak-pihak yang berkepentingan atas aktivitas atau kinerja yang telah dicapai selama periode tertentu. Sanksi daripada keterlambatan penyampaian laporan keuangan keuangan kepada KPPN Manado adalah dalam bentuk surat teguran yang dikirim kepada instansi berisi penundaan SP2D untuk pengajuan SPM berjalan.

\section{Penilaian Kinerja}

Penilaian kinerja dalam pelaksanaan dekonsentrasi bidang LH berdasarkan Permen LH No 09 Tahun 2014 dilaksanakan dengan : (a) membandingkan hasil capaian pelaksanaan kegiatan terhadap indikator kinerja dan target yang ditetapkan; dan (b) melaksanakan pendalaman terhadap kendala dan permasalahan yang dihadapi dalam pelaksanaan sebagaimana dilihat dalam tabel 4.3 , data realisasi bahwa pada tahun 2014 sebesar 86, $5 \%$ dan mengalami penurunan pada realisasi tahun 2015 hanya sebesar 77, $7 \%$ hal ini disebabkan oleh rasionalisasi anggaran pusat.

Kebijakan pelaksanaan dekonsentrasi yang diterapkan oleh pemerintah pusat berdampak juga kepada penilaian kinerja pelaksanaan dekonsentrasi pada Pemerintah daerah sehingga mempengaruhi Penilaian kinerja khususnya pada BLH Prov Sulut. Namun dapat dipastikan bahwa rasionalisasi anggaran tersebut tidak mempengaruhi kesejahteraan masyarakat. Pemerintah pusat dan pemerintah daerah penyelenggara dekonsentrasi harus mampu menitikberatkan fokus belanja APBN pada kegiatan atau program yang dampaknya langsung dapat dirasakan oleh masyarakat.

Terkait pengelolaan dana dekonsentrasi pada tahun 2014 menunjukan realisasi berada pada 86,9 \% dan pada tahun 2015 sebesar 80,06 \% capaian kinerja tersebut dinilai sudah cukup baik karena adanya tanggungjawab daripada pelaksana teknis untuk membina perusahaan atau stakeholder sesuai dengan peraturan yang berlaku. Hal ini sejalan dengan pendapat Agus (2012) yang berpandangan bahwa tanggungjawab adalah suatu bentuk sikap dan perilaku seseorang dalam melaksanakan tugas dan kewajibannya baik terhadap diri sendiri, masyarakat, lingkungan alam, lingkungan sosial budaya, negara dan Tuhan.

Penilaian kinerja bertujuan untuk mengevaluasi kebijakan pelimpahan kewenangan dekonsentrasi dalam bidang lingkungan hidup. Hasil penilaian kinerja bersifat terbuka dan disusun 
sesuai dengan tata laksana pemantauan, evaluasi, penilaian kinerja dan pembinaan. Menurut Mahmudi (2002), indikator kinerja didefinisikan sebagai ukuran kuantitatif atau kualitatif yang menggambarkan tingkat pencapaian suatu sasaran atau tujuan yang telah ditetapkan. Sedangkan pengukuran kinerja didefinisikan sebagai pengukuran hasil dan efisiensi jasa atau program berdasarkan basis reguler (tetap, teratur). Untuk melakukan pengukuran kinerja, diperlukan informasi akuntansi terutama dalam menentukan indikator kinerja (performance indicator) sebagai dasar penilaian kinerja.

\section{Pembinaan dan Pengawasan}

Pengawasan penyelenggaraan dekonsentrasi pada BLH Prov Sulut dilaksanakan oleh Inspektorat Kementerian Lingkungan Hidup dan Kehutanan. Inspektorat dapat bekerjasama dengan Badan Pengawasan Daerah dan/atau Inspektorat Provinsi secara selektif berdasarkan tingkat-tingkat urgensinya melalui mekanisme kesepakatan penugasan Menteri kepada Gubernur. Namun pada BLH Prov Sulut, pengawasan dekonsentrasi dilaksanakan oleh Inspektorat KLHK paling sedikit 1 (satu) kali dalam 1 (satu) tahun. Pegawasan dilakukan terhadap laporan manajerial dan laporan akuntabilitas pelaksanaan dekonsentrasi bidang LH. Penanggungjawab terhadap pembinaan dan pengawasan penyelenggaraan dekonsentrasi pada BLH Prov Sulut dilakukan oleh Kepala Badan Lingkungan Hidup selaku Kuasa Pengguna Anggaran dekonsentrasi, Sekretaris BLH Sulut selaku Pejabat Pembuat Komitmen.

Fungsi pembinaan dan pengawasan penyelenggaraan dekonsentrasi pada BLH Prov Sulut menjadi perhatian pimpinan sekaligus mendapat perhatian khusus dari pejabat yang ada dalam lingkup pengelolaan dekonsentrasi untuk bersinergi agar dapat mengembangkan strategi dalam pelaksanaan program khusnya program kegiatan dekonsentrasi bidang LH secara sistematis dapat terlaksana dengan baik. Menurut Sirait (1991:143), strategi pembinaan merupakan proses pemilihan tujuan, penentuan kebijakan dan program yang perlu untuk mencapai sasaran tertentu dalam rangka mencapai tujuan dan penetapan metode yang perlu untuk menjamin agar kebijakan dan program tersebut terlaksana. Hasil penelitian dilapangan ditemukan bahwa masih terdapat kelalaian terhadap pengawasan dekonsentrasi pada BLH Provinsi Sulut disebabkan ASN kurang memahami akan tugas dan fungsinya masing-masing.

Hasil penelitian menunjukan bahwa terkadang proses koordinasi pelaksanaan kegiatan antar bidang masih terhalang dengan berbagai kegiatan. Dalam praktek administrasi khususnya pada BLH Prov Sulut, koordinasi dianggap sebagai satu hal yang umum. Namun seringkali koordinasi mudah diucapkan tetapi sulit untuk dilaksanakan. Hubungan keterkaitan jadwal pelaksanaan dekonsentrasi antar kegiatan sejenis namun pelaksanaannya tidak terkoordinasi dengan baik. Dalam kegiatan tugas lapangan terhalang dengan jadwal pelaksanaan kegiatan serupa tanpa bisa dikendalikan oleh pimpinan.

\section{Penutup}

Kesimpulan dalam penelitian ini adalah: 1) Arah kebijakan dekonsentrasi bidang lingkungan hidup terkait dengan Indeks Kualitas Lingkungan Hidup (IKLH) pada Badan Lingkungan Hidup Provinsi Sulawesi Utara masih terus perlu dilakukan penyempurnaan, terutama pada saat menentukan dasar program dekonsentrasi dalam memperhitungkan kriteria/parameter pengukuran sebagai ukuran pencapaian kualitas pembangunan sebagai dasar tujuan utama penyelenggaraan dekonsentrasi bidang lingkungan hidup di Sulawesi Utara; 2) Perencanaan dekonsentrasi bidang lingkungan hidup pada BLH Provinsi Sulut sudah berjalan sesuai peraturan yang ada, namun penyusunan perencanaan dekonsentrasi belum efektif dan efisien memaksimalkan sumber dana secara optimal dalam memprioritaskan kebutuhan daerah. Untuk itu perencanaan masih perlu terus dimatangkan sehingga benar-benar memperhatikan kebutuhan prioritas daerah melalui sektor lingkungan hidup; 3) Walaupun Penganggaran dekonsentrasi bidang lingkungan hidup pada BLH Prov Sulut telah dipantau secara terus menerus berdasarkan peraturan yang berlaku, namun output penganggaran dekonsentrasi wajib disesuaikan dengan kode akun sesuai prioritas juknis sehingga tidak keluar dari aturan yang telah ditetapkan oleh pemerintah pusat. Peran pimpinan guna mendorong pelaksanaan penganggaran dekonsentrasi menjadi catatan penting sehingga ada keterbukaan dalam menumbuhkan komitmen bersama dalam melaksanakan akuntabilitas program dan kegiatan dalam menunjang anggaran dekonsentrasi; 4) Pelaksanaan dekonsentrasi bidang lingkungan hidup merupakan bentuk kesatuan pekerjaan atau kegiatan yang dilaksanakan oleh para pegawai BLH Provinsi Sulut dengan penuh rasa tanggungjawab dan yang memiliki aspek teknis khusus serta saling berkaitan satu sama lain menurut sifat atau pelaksanaanya dalam mencapai tujuan organisasi perangkat daerah, namun penghambat dalam mengukur kinerja atas realisasi penyerapan anggaran pelaksanaan dekonsentrasi pada BLH 
Provinsi Sulut tidak terlepas daripada rasionalisasi anggaran. Hal tersebut menyebabkan target yang telah ditetapkan belum sesuai dengan pencapaian realisasi; 5) Pelaporan dekonsentrasi bidang lingkungan hidup pada BLH Provinsi Sulut sudah berjalan dengan baik namun masih adanya keterlambatan dalam pelaporan dekonsentrasi ke KPPN. Peran dan fungsi dari PPTK pada BLH Prov Sulut menjadi perhatian khusus dalam prosedur untuk menilai atas kewajaran dan transparansi atas pelaporan teknis kegiatan maupun laporan keuangan. Evaluasi secara independen efektif dalam mengontrol kewajaran terhadap pelaporan dan monitoring pelaksanaan bidang teknis dekonsentrasi guna menghindari sanksi kedepannya; 6) Penilaian kinerja bidang lingkungan hidup didasarkan pada hasil evaluasi, hambatan yang masih ditemukan dalam pelaksanaannya terkait masih minimnya fasilitas atas sarana dan prasarana yang ada sebagai penunjang penyelenggaraan kegiatan dekonsentrasi, laporan yang belum sesuai serta keterbatasan SDM memerlukan tindakan korektif dalam menumbuhkan partisipasi serta rasa tanggungjawab dalam pelaksanaan program dekonsentrasi. Penilaian kinerja pelaksanaan dekonsentrasi yang diterapkan oleh pemerintah pusat berdampak juga kepada kondisi penilaian kinerja pelaksanaan dekonsentrasi Pemerintah daerah sehingga mempengaruhi Penilaian kinerja khususnya pada BLH Provinsi Sulut; 7) Pembinaan dan pengawasan penyelenggaraan dekonsentrasi bidang lingkungan hidup pada BLH Provinsi Sulut telah dilakukan secara berjenjang namun tidak luput daripada perhatian pimpinan. Masih adanya kelalaian terhadap pembinaan dan pengawasan dekonsentrasi disebabkan perilaku organisasi yang kurang berkomitmen dan belum konsisten menjalankan tugas dan fungsi masing-masing pelaksana.

Saran yang dapat diberikan dari penelitian ini yaitu: 1) Perencanaan dekonsentrasi diharapkan dapat terus dikoordinasikan dengan biro perencanaan KLHK agar supaya penyusunan perencanaan yang ada dapat diimplementasikan melalui pembahasan dan kemudian dapat disepakati bersama antara biro perencanaan dan satker dekonsentrasi sesuai dengan juknis yang ada; 2) Agar penyelenggaraan dekonsentrasi berjalan efektif, diperlukan penyesuaian penganggaran dekonsentrasi dengan prioritas pembangunan nasional sesuai dengan petunjuk teknis bidang lingkungan hidup, sehingga penganggaran dekonsentrasi yang telah tertata tidak keluar dari mekanisme peraturan yang sudah ditetapkan oleh pemerintah pusat; 3) Kepedulian dan komitmen terhadap peran dan fungsi dari PPTK penyelenggaraan dekonsentrasi pada BLH Provinsi Sulut perlu diefektifkan sehingga pelaporan dan monitoring pelaksanaan bidang teknis dekonsentrasi terus dapat dipantau secara berkesinambungan dan mampu menghasilkan sumberdaya manusia yang handal dan berkompetensi; 4) Penyelenggara dekonsentrasi wajib menjalankan prosedur secara sistematis dan bertanggungjawab sesuai dengan petunjuk teknis yang berlaku, memahami dengan baik dan benar peran atas tugas pokok dan fungsi masing-masing penyelenggara, menjalankan fungsi koordinasi pengendalian internal dalam mewujudkan akuntabilitas pengelolaan keuangan negara; 5) Perlunya peningkatkan pengawasan anggaran secara lebih efektif dan efisien agar penyelenggaraan dekosentrasi pada BLH Provinsi Sulut bukan hanya mendukung program pemerintah namun dapat juga di publish dengan menerapkan online sistem.

\section{Daftar Pustaka}

American Accounting Association Committe on Accounting for Human Resource. (1973). Report of the committe on Human Resource Accounting. Vol. XLVII.

Amin Rahmanurrasjid (2008). Akuntabilitas Dan Transparansi Dalam Pertanggungjawaban Pemerintah Daerah Untuk Mewujudkan Pemerintahan Yang Baik Di Daerah (Studi Di Kabupaten Kebumen). Tesis.

Agus Subroto (2009), Akuntabilitas Pengelolaan Dana Desa (Studi Kasus Pengelolaan Alokasi Dana Desa Di Desa-Desa Dalam Wilayah Kecamatan Tlogomulyo Kabupaten Temanggung Tahun 2008 ). Tesis Program Studi Magister Sains Akuntansi Program Pasca Sarjana Universitas Diponegoro Semarang 2009.

Agus, Suprijono (2012). Metode dan Model-Model Mengajar. Bandung: Alfabeta.

Armstrong, Michael dan Angela Baron, 1998. Performance Management, Institute of Personel and Development, London.

Choiri, Nur hidayatul, (2006). Akuntabilitas Kinerja Dinas Pendidikan Kabupaten Malang (Studi Kasus tentang Akuntabilitas Administratif Pelaksana Program Wajib Belajar Pendidikan Dasar Sembilan Tahun di Kecamatan Bululawang Kabupaten Malang.

Conor (1974). Monitoring Pekerjaan. Yogyakarta. 
Cooper, Philip (1995), "Accountability and Administrative Reform: Toward a Convergence and Beyond", in B. Guy Peters and Donald Savoie (eds.), Governance in a Changing Environment, McGill-Queens University Press, Montreal, Canada.

Creswell, John W (2007). Research Design: Qualitative and Quantitative Approaches. California: Sage Publications, Inc.

Erwantosi (2010), Analisis Efektivitas, Akuntabilitas dan Transparansi Bantuan Operasional Sekolah pada Sekolah Menengah Pertama di Kota Padang. Tesis.

Gibson, James L (1997). Organisasi. Jakarta: Erlangga.

Hansen dan Mowen (2007). Akuntansi Manajemen, Edisi 7 Buku 2. Jakarta : Salemba Empat.

Hardjasoemantri, K. (2003). Good Governance dalam Pembangunan Berkelanjutan di Indonesia. Dalam: Makalah Untuk Lokakarya Pembangunan Hukum Nasional ke VIII - Bali.

Hartanti Erlina (2010). Alokasi Dana Dekonsentrasi Kementerian Pendidikan Nasional Kesesuaiannya Dengan Peraturan Pemerintah Nomor 38 Tahun 2007. Journal FE UI, 2010. Tesis.

Hendra Permana L (2013). Analisis Dana Dekonsentrasi Dan Dana Apbd Sektor Pendidikan Di Provinsi Jawa Tengah Tahun 2003-2011. Journal Fakultas Ekonomika dan Bisnis Universitas Diponegoro.

Joko Widodo (2011). Membangun Birokrasi Berbasis Kinerja. Malang: Banyumedia Publishing.

Julian, R (1998). Accountability and Multilateral Global Governance: exploring the discourse of transparency and the role of secrecy. A thesis submitted to the University of Bristol in accordance with the requirement of the degree of Doctor of Philosophy in the Department of Politics, Faculty of Social Science (December, 1998).

Kadir Hamzah Basri, R. (2015). A Review of Characteristics and Experiences of Decentralization of Education. International Journal of Education \& Literacy Studies, Faculty of Educational Studies, Australian International Academic Centre, Australia Vol.3 No.1 January 2015.

Khemani, Stuti (2006). "Local Government Accountability for Service Delivery in Nigeria Journal of African Economies 15.

Krina (2003). Indikator dan Alat Ukur Prinsip Akuntabilitas, Transparansi dan Partisipasi. Jakarta.

Lembaga Administrasi Negara dan Badan Pengawasan Keuangan dan Pembangunan, "Akuntabilitas Dan Good Goverenance” Lembaga Admnistrasi Negara dan Badan Pengawas Keuangan dan Pembangunan, Jakarta, 2000.

Mahmudi (2002). Laporan Keuangan Sektor Publik Untuk Transparansi Dan Akuntabilitas Publik, Jurnal Pendidikan Akuntansi (JPAI), Yogyakarta.

Mahmudi, 2011. Akuntansi Sektor Publik. UII Press. Yogyakarta.

Mahsun, Mohamad, 2012, Pengukuran Kinerja Sektor Publik, BPFE-Yogyakarta, Yogyakarta.

Maksum, Hamid Muda. 2014. The Impact of Treasurer's Experience And Knowledge on The Effectiveness of The Administration and Preparation of The Accountability Reporting System in North Sumatera. Asian Journal of Finance \& Accounting, Faculty of Economics and Business, University of North Sumatera. Vol.6 No.2 2014.

Mardiasmo, 2005. Akuntansi Sektor Publik. Yogyakarta. Andi Yogyakarta.

Meidiza Dwi Orchidea (2016), Efektifitas Pelaksanaan Kebijakan Dana Dekonsentrasi dalam Peningkatan Kualitas Lingkungan Hidup. Tesis Institut Pertanian Bogor 2016.

Muhammad Zaenuddin (2006), Evaluasi Pelaksanaan Otonomi Daerah dengan Alat Analisis Derajat Otonomi Fiskal Daerah (Studi Kasus 5 Kabupaten/Kota di Propinsi Daerah Istimewa Yogyakarta, 1999-2006 ). Thesis.

Mulyadi (2007). Sistem Akuntansi Penyusunan Prosedur dan Metode. Yogyakarta: Alfabeta.

Munawir (2010) Analisa Laporan Keuangan. Yogyakarta: Liberty.

Nadeak H, (2012) Studi dana Dekonsentrasi dan Tugas Pembantuan di Lingkungan Kementerian Dalam Negeri. Thesis. Jurnal Bina Praja | Volume 4 Nomor 1 Edisi Maret 2012.

Nafarin,M (2007). Penganggaran Perusahaan.Jakarta:Salemba Empat.

Nining Zainal, 2008, Analisis Kesesuaian Tugas Pokok dan Fungsi dengan Kompetensi Pegawai pada Sekretariat Pemerintah Kota Makassar, Skripsi.

Nurzaimah, R (2014). Analysis on the Timeliness of the Accountability Report by the Treasurer Spending in Task Force Units in Indonesia. International Journal of Academic Research in Accounting, Finance and Management Sciences, Faculty of South Sumatera Vol.4 October 2014.

Peraturan Menteri Keuangan Nomor 156/PMK.07/2008 tentang Pedoman Pengelolaan Dana Dekonsentrasi dan Dana Tugas Pembantuan. 
Peraturan Menteri Pendayagunaan Aparatur Negara Nomor 135/M.PAN/9/2004

tentang Pedoman Evaluasi Laporan Akuntabilitas Kinerja Instansi Pemerintah.

Peraturan Pemerintah No. 7 Tahun 2008 tentang Dekonsentrasi dan TP.

Peraturan Pemerintah Republik Indonesia Nomor 39 Tahun 2001 tentang Pembagian Wilayah dan Wewenang.

Peraturan Presiden Nomor 29 Tahun 2014 tentang Sistem Akuntabilitas Kinerja Instansi Pemerintah.

Oosterveer, P., B. V. Vliet (2010). Environmental systems and local actors: Decentralizing environmental policy in Uganda. J. Environ. Manag. 45, pp. 284-295. doi:10.1007/s002670099423-4.

PKP2A III LAN Samarinda Tahun 2007 dengan Judul “Kajian Tentang Evaluasi Kinerja Pemerintah Propinsi dalam Penyelenggaraan Kewenangan Dekonsentrasi"

Pitono, Andi (2012). Asas Dekonsentrasi dan Asas Tugas Pembantuan dalam Penyelenggaraan Pemerintahan. Journal Kebijakan Publik, Volume 3, Nomor 1, Maret 2012, hlm. 1-55.

Posner, Paul L. (2002), "Accountability Challenges of Third Party Government" in Lester Salamon (ed.), The Tools of Government, Oxford University Press, New York.

Rahman, A, Darwanis and Siswar, D. (2012). Pengaruh Kompetensi, Pelatihan dan Sistem Akuntansi Instansi terhadap Kualitas Pertanggungjawaban Laporan Keuangan Dana Dekonsentrasi (Studi Pada Satuan Kerja Pemerintah Aceh yang Mengelola Dana Dekonsentrasi). Jurnal Akuntansi Pascasarjana Universitas Syiah Kuala Banda Aceh. Volume 2, No. 1, pp.1-20. Retrieved Sept 20, 2014.

Rasul, Syahrudin (2002). Pengintegrasian Sistem Akuntabilitas Kinerja dan Anggaran. Jakarta: Detail Rekord.

Rini. A (2010). Evaluasi Terhadap Akuntabilitas Dekonsentrasi Pada Departemen Energi Dan Sumber Daya Mineral. Journal FE UI, 2010. Tesis

Rondinelli, Deniis A and Shabir Cheema G (1983). Implementing Decentralization Policies : An Introduction in Decentralization and Development, Policy Implementation in Developing Countries, Sage Publication, Beverly Hills.

Rudianto (2013). Akuntansi Manajemen Informasi untuk Pengambilan Keputusan Strategis. Jakarta: Erlangga.

Sedarmayanti (2003). Good Governance (Kepemerintahan Yang Baik) Dalam Rangka Otonomi Daerah, Mandar Maju, Bandung.

Sirait Alfonsus (1991). Manajemen. Jakarta: P.T Gelora Aksara.

Soenobo Wirjosoegito (2004). Proses \& Perencanaan Peraturan Perundangan, Ghalia Indonesia, Jakarta.

Sumedi, Simatupang P, Sinaga B, Firdaus M (2013). Dampak dana dekonsentrasi Kementerian Pertanian dan Pengeluaran daerah pada sektor pertanian terhadap kinerja pertanian daerah. J Agro Ekon. 31 (02):97-113.

Sugiyono (2011). Metode Penelitian Pendidikan Pendekatan Kuantitaf, Kualitatif, dan $R \& D$. Bandung: Alfabeta.

Tendi Haruman dan Sri Rahayu (2007). Penyusunan Anggaran Perusahaan, Penerbit Graha Ilmu. Bandung: Fakultas Bisnis dan Manajemen Universitas Widyatama.

Daerah.

Undang-Undang Nomor 5 Tahun 1974 tentang Pokok-Pokok Pemwerintahan Di

Undang-Undang No. 33 Tahun 2004 tentang Perimbangan Keuangan Antara Pemerintah Pusat dan Pemerintah Daerah.

Undang Undang Nomor 17 Tahun 2003 tentang Keuangan Negara.

Undang-Undang No. 33 Tahun 2004 tentang Perimbangan Keuangan antara Pemerintah Pusat dan Pemerintahan Daerah.

Undang Undang Nomor 1 Tahun 2004 tentang Perbendaharaan Negara.

Undang Undang Nomor 15 Tahun 2004 tentang Pemeriksaan Tanggung Jawab dan Pengelolaan Keuangan Negara.

Wiratna Sujarweni (2015). Akuntansi Sektor Publik. Pustaka Baru Press. Yogyakarta. 